\title{
Bluetongue Virus Infection in Ruminants: A Review Paper
}

\author{
Mateus de Oliveira Vial, Brennda Vitorino Corrêa, Ana Clara Malegoni, Tayná Bolsam da Silva, \\ Lara Cassaro, Luiz Alexandre Moscon, Diogo Almeida Rondon, Clairton Marcolongo Pereira*
}

Faculdade de Medicina Veterinária, Centro Universitário do Espírito Santo (UNESC), Colatina, Brazil

Email: *clairton.marcolongo@terra.com.br

How to cite this paper: de Oliveira Vial, M., Corrêa, B.V., Malegoni, A.C., da Silva, T.B., Cassaro, L., Moscon, L.A., Rondon, D.A. and Pereira, C.M. (2021) Bluetongue Virus Infection in Ruminants: A Review Paper. Open Access Library Journal, 8: e7150.

https://doi.org/10.4236/oalib.1107150

Received: January 13, 2021

Accepted: February 6, 2021

Published: February 9, 2021

Copyright $\odot 2021$ by author(s) and Open Access Library Inc.

This work is licensed under the Creative Commons Attribution International License (CC BY 4.0).

http://creativecommons.org/licenses/by/4.0/

(c) (i) Open Access

\begin{abstract}
Bluetongue is an infectious, viral, non-contagious disease, caused by the virus of the genus Orbivirus and family Reoviridae, being transmitted by hematophagous vectors of the genus Culicoides to domestic and wild ruminants. The disease mainly affects sheep. The infection is related to the climatic conditions of high temperatures and high humidity, which favor the proliferation of vectors. The disease is characterized by systemic hemorrhagic viral fever, caused by vascular injury as a result of the virus-mediated endothelial injury. The lesions are located in the upper gastrointestinal tract, skin and lungs. The clinical signs presented by the animals are fever, edema of the face, lips, snout and ear; sialorrhea, hyperemic oral mucosa and serous to mucopurulent nasal discharge. The diagnosis is made by laboratory analysis, with isolation of the virus by inocula, embryonated eggs or cell cultures; by identification of the agent; by virus-neutralization or by the detection of specific antibodies. There is no specific treatment. In animals showing clinical signs, prophylactic antibiotic therapy is performed. Vaccination and control of vector mosquitoes are the best methods of disease control.
\end{abstract}

\section{Subject Areas \\ Veterinary Medicine}

Keywords

Ruminants, Virus, Bluetongue, Ethiology, Orbivirus, Culicoides

\section{Introduction}

Bluetongue (BT) is a non-contagious viral infectious disease that affects ruminants and other animal species. The bluetongue virus (BTV) belongs to the genus Orbivirus and the family Reoviridae, being transmitted by hematophagous 
vectors of the genus Culicoides [1] [2]. According to the World Organization for Animal Health (OIE), bluetongue is a notifiable disease [3]. This disease causes great socioeconomic impact with direct losses of affected herds and indirectly with restrictions on international trade in animals and their products [4] [5].

The disease occurs when sensitive species are introduced into areas with circulating virulent strains or when virulent strains of bluetongue are inserted into herds of ruminants that have not been previously exposed [3]. Bluetongue hosts ruminants, camelids and wild canids. The species most susceptible to developing the clinical picture are sheep when compared to other ruminants. Among sheep breeds, European breeds are more sensitive than tropical and subtropical breeds [6]. This study presents the latest information about bluetongue disease transmission, prevention and potential therapeutic options.

\section{Etiology and Epidemiology}

The BT virus belongs to the genus Orbivirus and to the family Reoviridae. Its most relevant characteristics are the double strand of RNA, icosahedral shape, non-enveloped and replication occurs in the cytoplasm of cells [6]. At least 29 serotypes of BTV are identified in the world, however viral strains of the same serotype can present different types of virulence even in the case of ruminants sensitive to disease [7].

Bluetongue occurs mainly in tropical climates and temperate regions of the world, due to the large distribution of mosquito vectors of the genus Culicoides [8]. The species responsible for the transmission of the disease are different for each region, in Africa and Asia Culicoides imicola, in Australia Culicoides brevitarsis, in America Culicoides sonorensis and in Northern Europe the most likely transmitters are Culicoides obsoletus, Culicoides scoticus and Culicoides pulicaris [9].

Only after an incubation period of approximately ten days, after ingestion of blood infected with the virus, do Culicoides dipterans become infectious. Females once infected persist with BTV for the rest of their lives [8].

BTV transmission occurs throughout the year in temperate regions. However, the infection is seasonal in these areas as it occurs in late summer and in the fall months [7]. In places of livestock activity where there is a large group of susceptible vectors and hosts, BT transmission is intensified [7].

\section{Transmission}

The main form of transmission of bluetongue between animals is through the blood meal of blood-sucking diptera of the genus Culicoides. Because sheep and goats have a shorter gestation period of five months, the intrauterine transmission route is less important, although it has been proven in the literature [6]. Currently, studies report transmission by direct contact, possibly by aerosol with BTV-26 between animals. They also suggest vertical transmission in animals, with live attenuated vaccine strains from BTV [8]. 
The transplacental route is of great economic importance because it causes abortions, stillbirths and unviable fetuses [9]. Vinomack, et al. (2020) [10] describe that infected animals can present abortions, genital and congenital malformations and neurological disorders. Oral transmission can occur through ingestion of contaminated placenta. Inoculation of contaminated needles in the subcutaneous tissue may also be a possible route of transmission [9].

\section{Physiopathogenia and Clinical Signs}

After infection, the virus replicates in the peripheral lymph nodes and the virus appears in the circulation in three to six days. Peak viremia occurs seven to eight days after infection, culminating in a febrile peak. Viremia in sheep hardly lasts for more than 14 days, but can reach up to 40 days. Cattle are considered important reservoirs of the disease because they maintain a viremia of $90-120$ days, due to differences in the immune response of these animals. The virus is found associated with red blood cells, and another small free part in the plasma. After the natural course of the disease, the animal acquires immunity against the specific serotype of the infection, however, it can become infected with another serotype [6]. This disease is characterized by systemic hemorrhagic viral fever, caused by a vascular lesion as a result of the virus-mediated endothelial injury, lesions located in the upper gastrointestinal tract, skin and lungs [8]. Due to the deterioration of the endothelium, which interferes with its function, there is an increase in vascular permeability, thus causing edema, vascular thrombosis, tissue infarction, necrosis, and hemorrhage [11]. The bluetongue lesions have edematous, hemorrhagic, and erosive characteristics, in which they can progress to cyanosis of the tongue, thus characterizing the name of the disease [9].

The clinical signs are varied, and sialorrhea, hyperemia of the mucous membranes and tearing may be observed [8]. The commonly observed clinical signs among ruminant species, such as in sheep, cattle, goats, and deer, are shown in Table 1.

Table 1. Clinical signs of bluetongue disease in ruminants.

\begin{tabular}{cl}
\hline SPECIES & \multicolumn{1}{c}{ CLINICAL SIGNS } \\
\hline & $\begin{array}{l}\text { Hyperthermia; Hyperemia of the oral mucosa; sialorrhea; tearing; nasal } \\
\text { discharge; peri-ocular and peri-articular hyperemia; wool loss; edema of the } \\
\text { tongue, lips, ears, and face; submandibular, neck and pulmonary edema; } \\
\text { petechiae; snout and nostril erosions; necrotic lesions in the oral mucosa; } \\
\text { cyanosis of the tongue; degeneration of the neck musculature; emaciation; } \\
\text { abortions, and fetal malformations. }\end{array}$ \\
& $\begin{array}{l}\text { Rarely symptomatic. When affected, they may present with sialorrhea, } \\
\text { hyperthermia, and disseminated dermatitis. }\end{array}$ \\
Cattle & $\begin{array}{l}\text { Mild or inapparent signs. Mild hyperemia of the conjunctiva and nasal } \\
\text { mucosa. }\end{array}$ \\
Goer & Signs like those presented by sheep.
\end{tabular}

The tongue can stick out of the mouth, thus causing problems with swallow- 
ing and regurgitation events [2]. Due to lesions in the oral cavity, which are painful, animals are reluctant to eat, leading to progressive weight loss, and in more severe cases, they do not drink water [8]. Dyspnea caused by pulmonary edema in super-acute cases causes death by asphyxia [6]. This pulmonary edema is characteristic of bluetongue and may be associated with acute bacterial bronchopneumonia [8]. Affected animals present lameness in more than one limb and diffuse redness at the coronary edge of the hoof due to coronitis observed from the 8 th to the 14th day after infection. In more severe cases of the disease, the presence of exudate around the coronary rim of the hoof is identified, leaving animals reluctant to stand or move, becoming bent or kneeling [9].

\section{Macroscopic and Microscopic Findings}

Macroscopic changes in the post-mortem examination include necrosis and hemorrhage of the mucosa of the upper gastrointestinal tract of the oral cavity and pre-stomachs, edema and hemorrhage of the subcutaneous and lymph nodes, pulmonary edema commonly found in severe cases, pleural and pericardial effusion, edema of the abdominal muscle, head and neck fasciae, myocardial necrosis and skeletal muscles [12]. In animals submitted to necropsy, cyanosis of the tongue and oral mucosa, flaccidity and necrosis of the esophageal muscles, a large amount of foamy fluid in the trachea and bronchi region can be found. Microscopic findings may include macrophage infiltrate associated with necrotic muscle fibers and the intense proliferation of fibroblasts and collagen synthesis in areas of multifocal mineralization. In the region of the lip skin, perivascular infiltration of lymphocytes and eosinophils and neutrophilic infiltration within the bronchi and bronchioles can be observed [13].

\section{Diagnostic}

The diagnosis of bluetongue is made by isolating the virus by inocula, embryonated eggs or cell cultures; by identifying the agent by means of virus-neutralization (VN); or by detecting specific antibodies [14]. Techniques for detecting the virus in use are immunofluorescence, competitive ELISA (c-ELISA) which is highly sensitive for antigen detection, real-time RT-PCR, multiplex PCR for BTV RNA detection and the sequencing technique to obtain the complete genomic sequence of BTV [9]. When properly validated, the ELISA test is highly specific and sensitive to detect antibodies to most BTV serotypes and strains. Although the antibodies detected by the test persist for long periods after infection, it does not distinguish between animals that were naturally infected and those that were immunized with BTV vaccines [8].

Some diseases present similar lesions with BT, making it necessary to perform

a differential diagnosis based on the type and distribution of the lesions. Foot-and-mouth disease (AF) with erosive and vesicular lesions, Pest des Petits Ruminants and vesicular stomatitis [9]. 


\section{Treatment and Control}

There is no specific treatment for bluetongue. In animals that show clinical signs prophylactic antibiotic therapy is performed [15]. Antoniassi et al. (2010) [2] describe that the administration of sodium dipyrone, penicillin and dexamethasone acetate to the affected animals shows significant clinical improvement. Prevention against BT can be accomplished with vector control or with the use of prophylactic immunization [8]. Vaccines can be inactivated viruses or live attenuated viruses. Vaccines are manufactured according to the virus strains in each region. Vaccines with inactivated viruses are safer when compared to live attenuated ones [8]. The administration of live attenuated vaccines must be carried out before the reproductive phase to prevent fetal infections [8].

\section{Conclusions}

Bluetongue is a disease of economic importance that causes direct and indirect losses with restrictions on the marketing of animals and their by-products. Its geographical distribution is related to the climate of temperate regions, favoring the proliferation of Culicoides vectors.

BTV transmission occurs throughout the year in temperate regions. The infection is seasonal in these areas as it occurs in late summer and fall. The main form of transmission of bluetongue between animals is through the blood meal of blood sucking Diptera of the genus Culicoides, although the oral and transplacental route has also been described. BTV is characterized by systemic hemorrhagic viral fever, caused by lesions in the vascular endothelium mediated by the virus. The lesions are more evident in the upper gastrointestinal tract, skin, and lungs.

Immunofluorescence, competitive ELISA (c-ELISA), real-time RT-PCR and multiplex PCR are used to diagnose the disease.

Bluetongue disease has no specific treatment. And prophylactic measures should be adopted, such as vaccination and control of vector mosquitoes, to control the spread of the disease and minimize economic losses.

\section{Acknowledgements}

This work was supported by Fundação de Amparo à Pesquisa e Inovação do Espírito Santo (FAPES), and was financed in part by the Coordenação de Aperfeiçoamento de Pessoal de Nível Superior (CAPES), Brasil-Finance code 001.

\section{Conflicts of Interest}

All authors declared that they do not have any conflict of interest to disclose.

\section{References}

[1] Maclachlan, N.J., Drew, C.P., Darpel, K.E. and Worwa, G. (2009) The Pathology and Pathogenesis of Bluetongue. Journal of Comparative Pathology, 141, 1-16. https://doi.org/10.1016/j.jcpa.2009.04.003 
[2] Antoniassi, N.A.B., Pavarini, S.P., Ribeiro, L.A.O., Silva, M.S., Flores, E.F. and Driemeier, D. (2010) Alterações clínicas e patológicas em ovinos infectados naturalmente pelo vírus da língua azul no Rio Grande do Sul. Pesquisa Veterinária Brasileira, 30, 10101016. http://dx.doi.org/10.1590/S0100-736X2010001200002

[3] Balaro, M.F.A., Lima, M.S., Fava, C.D., Oliveira, G.R., Pituco, E.M., Brandão, F.Z. (2014) Outbreak of Bluetongue Virus Serotype 4 in Dairy Sheep in Rio de Janeiro, Brazil. Journal of Veterinary Diagnostic Investigation, 26, 567-570. https://doi.org/10.1177\%2F1040638714538020

[4] Gard, G.P., Weir, R.P. and Walsh, S.J. (1988) Arboviruses Recovered from Sentinel Cattle Using Several Virus Isolation Methods. Veterinary Microbiology, 18, 109-118. https://doi.org/10.1016/0378-1135(88)90057-0

[5] Velthuis, A.G., Saatkamp, H.W., Mourits, M.C., De Koeijer, A.A. and Elbers, A.R. (2010) Financial Consequences of the Dutch Bluetongue Serotype 8 Epidemics of 2006 and 2007. Preventive Veterinary Medicine, 93, 294-304.

https://doi.org/10.1016/j.prevetmed.2009.11.007

[6] Balaro, M.F.A., Silva, P.C.A.R. and Brandão, F.Z. (2017) Língua azul: Desmistificando a doença. Revista Acadêmica Ciência Animal, 15, 21-31. http://dx.doi.org/10.7213/academica.15.S02.2017.A0

[7] Mayo, C., Mcdermott, E., Kopanke, J., Stenglein, M., Lee, J., Mathiason, C., Carpenter, M., Reed, K. and Perkins, T.A. (2020) Ecological Dynamics Impacting Bluetongue Virus Transmission in North America. Frontiers in Veterinary Science. 7, 1-13. https://doi.org/10.3389/fvets.2020.00186

[8] Maclachlan, N.J., Mayo, C.E., Daniels, P.W., Savini, G., Zientara, S. and Gibbs, E.P.J. (2015) Bluetongue. Revue Scientifique Technical (Internacional Office of Epizootics), 34, 329-340. https://doi.org/10.20506/rst.34.2.2360

[9] Rojas, M.J., Martin, D.R., Martín, V. and Sevilla, N. (2019) Diagnosing Bluetongue Virus in Domestic Ruminants: Current Perspectives. Veterinary Medicine: Research and Reports, 10, 17-27. https://doi.org/10.2147/VMRR.S163804

[10] Vinomack, C., Rivière, J., Bréard, E., Viarouge, C., Postic, L., Zientara, S., Vitour, D., Belbis, G., Spony, V., Pagneux, C., Sailleau, C. and Zanella, G. (2020) Clinical Cases of Bluetongue Serotype 8 in Calves in France in the 2018-2019 Winter. Transboundary and Emerging Diseases, 67, 1401-1405.

https://doi.org/10.1111/tbed.13466

[11] Coetzee, P., Stokstad, M., Venter, E.H., Myrmel, M. and Vuuren, M.V. (2012) Bluetongue: A Historical and Epidemiological Perspective with the Emphasis on South Africa. Virology Journal, Article No. 198.

https://doi.org/10.1186/1743-422X-9-198

[12] Maclachlan, N.J. (2017) Bluetongue: History, Global Epidemiology, and Pathogenesis. Preventive Veterinary Medicine, 102, 107-111. https://doi.org/10.1016/j.prevetmed.2011.04.005

[13] Guimarães, L.L.B., Rosa, J.C.C., Matos, A.C.D., Cruz, R.A.S., Guedes, M.I.M.C., Dorella, F.A., Figueredo, H.C.P., Pavarini, S.P., Sonne, L., Lobato, Z.I.P. and Driemeier, D. (2017) Identification of Bluetongue Virus Serotypes 1, 4, and 17 Co-Infections in Sheep Flocks during Outbreaks in Brazil. Research in Veterinary Science, 113, 87-93. https://doi.org/10.1016/j.rvsc.2017.09.001

[14] Cunha Filho, L.F.C., Sbizera, M.C.R., Barreto, J.V.P., Pituco, E.M., Lorenzetti, E., Lunardi, M., Patelli, T.H.C. and Matias, B.F. (2019) Bluetongue Disease in Sheep: A Review. Arquivos Instituto Biologico, 86, 1-10. https://doi.org/10.1590/1808-1657001342018 
[15] Radostits, O.M., GAY, C.C., Hinchcliff, K.W. and Constable, P.D. (2007) Veterinary Medicine: A Textbook of the Diseases of Cattle, Horse, Sheep, Pigs and Goats. Elsevier, Philadelphia. 